\title{
GUIDELINES FOR TREATMENT OF DEGENERATIVE LUMBAR SPONDYLOLISTHESIS
}

\author{
DIRETRIZES PARA TRATAMENTO DE ESPONDILOLISTESE LOMBAR DEGENERATIVA
}

GUÍA DE TRATAMIENTO DE LA ESPONDILOLISTESIS LUMBAR DEGENERATIVA

Carmen Yossaleth Briceño-GonzálezZ1, Adrián García-Suarez', Eulalio Elizalde-Martínez¹, Mario Antonio Domínguez-de la Peña', Rubén Torres-González ${ }^{1}$, José Manuel Pérez-Atanasio ${ }^{1}$

1. Hospital de Ortopedia de la UMAE “Dr. Victorio de la Fuente Narváez”, Ciudad de México.

\begin{abstract}
Objectives: To determine the standard of treatment of degenerative lumbar spondylolisthesis in its different clinical presentations in UMAE Dr. Victorio de la Fuente Narváez. Methods: Six cases found in the literature were presented to 36 experts in spine surgery, along with treatment options, to thereby obtain a standard prescription for the treatment of degenerative lumbar spondylolisthesis. Analytical observational cross-sectional descriptive study. Results: It was found that the treatment of choice in cases of degenerative lumbar spondylolisthesis with axial symptoms is conservative. The surgical treatment of choice for both stable and unstable patients with radiculopathy and/or claudication is decompression + posterolateral graft + transpedicular instrumentation + discectomy (graft). Conclusions: We managed to define the degenerative lumbar spondylolisthesis treatment guidelines in our unit, which can serve as a basis for the development of a clinical practice guide.
\end{abstract}

Keywords: Spondylolisthesis; Spine; Therapeutics.

\section{RESUMO}

Objetivos: Determinar o padrão de tratamento de espondilolistese lombar degenerativa em suas diversas apresentações clínicas em UMAE Dr. Victorio de la Fuente Narváez. Métodos: Seis casos encontrados na literatura foram apresentados a 36 médicos especialistas em cirurgia de coluna, juntamente com opções de tratamento, para assim, obter um padrão de prescrição para o tratamento de espondilolistese degenerativa lombar. Estudo descritivo transversal observacional analítico. Resultados: Verificou-se que o tratamento de escolha para os casos de espondilolistese lombar degenerativa com sintomas axiais são conservadores. O tratamento cirúrgico de escolha para casos estáveis ou instáveis com radiculopatia e/ou claudicação é descompressão + enxerto posterolateral + instrumentação transpedicular + discectomia (enxerto). Conclusões: Foi possível definir as diretrizes de tratamento de espondilolistese lombar degenerativa em nossa unidade, que pode servir de base para o desenvolvimento de um guia de prática clínica.

Descritores: Espondilolistese; Coluna vertebral; Terapêutica.

\section{RESUMEN}

Objetivos: Conocer el patrón de tratamiento de la espondilolistesis lumbar degenerativa en sus diferentes presentaciones clínicas en la UMAE Dr. Victorio de la Fuente Narváez. Métodos: Se presentaron a 36 médicos expertos en cirugía de columna 6 casos basados en la literatura, junto con las posibilidades de tratamiento, para obtener de este modo un patrón de prescripción para el tratamiento de espondilolistesis lumbar degenerativa. Estudio observacional descriptivo transversal analítico. Resultados: Se encontró que el tratamiento de elección para los casos de espondilolistesis lumbar degenerativa con sintomatología axial es conservador. El tratamiento quirúrgico de elección para los casos estables o inestables con radiculopatía y/o claudicación es la descompresión + injerto posterolateral + instrumentación transpedicular + discectomía (injerto). Conclusiones: Se logró definir la guía de tratamiento de espondilolistesis lumbar degenerativa en nuestra unidad, lo que puede servir como fundamento en la elaboración de una guía de práctica clínica.

Descriptores: Espondilolistesis; Columna vertebral; Terapéutica.

\section{INTRODUCTION}

Degenerative lumbar spondylolisthesis is the acquired anterior displacement of one vertebra over the subjacent vertebra, associated with degenerative changes, without any change or defect to the vertebral ring. ${ }^{1}$

Degenerative spondylolisthesis occurs in patients older than 40 years of age and is rarely identified before this age. ${ }^{2}$

The most frequently affected segment is L4-L5 (in $85 \%$ of the cases), followed by L3-L4, and occasionally by L5-S1, and this displacement rarely exceeds $30 \% .^{2}$

The treatment for spondylolisthesis usually is focused on pain relief, muscle strengthening, and restoration of the range of lumbar mobility. Achieving these objectives allows the patient to return to normal activity without any type of restrictions.

Conservative treatment of spondylolisthesis includes the cessation of activity, rehabilitation with strengthening of the abdominal and paravertebral muscles, minimization of pelvic tilt, NSAIDs, and corticosteroid injections. ${ }^{3}$

Surgical treatment should be considered for patients with de- 
bilitating symptoms that do not respond to conservative treatment. ${ }^{4}$ Although the number of surgical options available to manage the disorder has increased in the last ten years, decompressive laminectomy with partial medial facetectomy and instrumented fusion continues to be the standard against which all other new techniques should be compared. The surgical techniques recommended by the NASS in its latest review are mentioned below. ${ }^{3}$

\section{Decompression without fusion}

Although decompression with fusion has become the most common technique for the treatment of degenerative spondylolisthesis, a number of recent studies have renewed interest in the use of decompression without fusion in several patient populations. ${ }^{5}$

\section{Decompression with non-instrumented fusion}

Currently, most patients with degenerative spondylolisthesis are treated with lumbar fusion and neural decompression. Laminectomy with fusion was shown to be superior to standalone laminectomy in a randomized study of 50 patients published in 1991 by Herkowitz and Kurz. ${ }^{6}$

\section{Decompression with posterolateral fusion and instrumentation}

The use of posterior instrumentation together with fusion for degenerative spondylolisthesis reduces the risk of pseudoarthrosis. However, its impact on the clinical results is not clear. Dynamic stabilization is associated with satisfactory clinical and radiographic results after 4 years in patients who underwent surgery for degenerative spondylolisthesis. ${ }^{7}$

\section{Intersomatic fusion}

The inclusion of intersomatic fusion within the context of degenerative spondylolisthesis has been an additional source of debate. In theory, it increases the surface area of the fusion and improves the initial stability of the construction.

In 2009, the NASS clinical guidelines raised the question as to whether 360-degree fusion has better outcomes when compared to decompression and posterolateral fusion. A few studies have addressed this question; however, they were unable to make any recommendations. ${ }^{3}$

In Mexico, there are currently no clinical practice guidelines for the treatment of degenerative lumbar spondylolisthesis, so this study might serve as a guide for their creation.

\section{METHODS}

A prospective survey of doctors specialized in spine surgery discussed six cases of degenerative lumbar spondylolisthesis with the objective of defining a standard for prescribing treatment for this pathology.

The study was conducted during the period from January 2016 to March 2016, in compliance with the regulations of the General Health Law for research material. This was a type I observational study, registered with the electronic registration system of the coordinator of health research of the Instituto Mexicano del Seguro Social under number R-2016-3401-25.

With the help of two experienced doctors working in the spine service and two educational technique experts, a questionnaire was created focusing on six characteristic cases of degenerative lumbar spondylolisthesis, including clinical presentation and images (dynamic radiographs and magnetic resonance) together with possible treatment options.

The power of the study was $80 \%$ and the confidence interval was $95 \%$. The formula was used to identify a difference in proportions between the group studied and that reported in the literature, based on Hulley's tables, ${ }^{8}$ obtaining a total of 36 doctors for the survey, including: a) doctors on the staff of the spine service of the UMAE, b) doctors not on the staff of the spine service, but with training, c) doctors in spinal surgery training. The subjects signed an informed consent form that clarified the confidential nature of the data obtained, and that the results would be used exclusively for research purposes.
During February and March 2016, the survey was administered electronically to each of the doctors.

Each of the cases included the following variables: instability, axial pain, radiculopathy, and claudication, presenting as possible responses:

1. Conservative treatment (oral analgesics, physical therapy, and rehabilitation)

2. Spinal decompression

3. Decompression + posterolateral graft + transpedicular instrumentation

4. Decompression + posterolateral graft + transpedicular instrumentation + discectomy (graft)

5. Anterior approach

6. $360^{\circ}$ spinal fusion

The confounding variables included were: being a member of the staff of the spine service, training, $>10$ years of spine surgery experience. For the purposes of this study, an experienced orthopedic surgeon was defined as a doctor with 10 or more years of clinical practice in spine surgery.

\section{RESULTS}

The cases were evaluated by 36 doctors, $90 \%$ of whom were male and $10 \%$ female. Forty-seven percent $(47 \%)$ were on the staff of the spine services of the orthopedic and traumatology hospitals of the UMAE Dr. Victorio de la Fuente Narváez. Eighty-three percent (83\%) were trained in spine surgery and $43 \%$ were spine surgery specialists.

Case 1 - Stable degenerative lumbar spondylolisthesis $-47.2 \%$ of the doctors surveyed opted for conservative management and 30\% chose surgical treatment based on decompression + posterolateral graft + transpedicular instrumentation + discectomy (graft).

Case 2 - Stable degenerative lumbar spondylolisthesis with data indicating radiculopathy $-63.8 \%$ of the doctors indicated decompression + posterolateral graft + transpedicular instrumentation + discectomy (graft).

Case 3 - Stable degenerative lumbar spondylolisthesis with claudication $-69.4 \%$ of the doctors surveyed opted for surgical treatment consisting of decompression + posterolateral graft + transpedicular instrumentation + discectomy (graft).

Case 4 - Unstable degenerative lumbar spondylolisthesis with only low back pain $-80.5 \%$ of the doctors surveyed chose conservative management.

Case 5 - Unstable degenerative lumbar spondylolisthesis with data indicating radiculopathy $-61.1 \%$ of the doctors elected surgical treatment based on decompression + posterolateral graft + transpedicular instrumentation + discectomy (graft).

Case 6 - Degenerative lumbar spondylolisthesis with claudication $-58 \%$ indicated decompression + posterolateral graft + transpedicular instrumentation + discectomy (graft).

Based on the results, we prepared a flowchart showing the treatment guidelines. (Figure 1)

\section{DISCUSSION}

The treatments recommended by the UMAE Dr Victorio de la Fuente Narváez were compared against the North American Spine Society (NASS) clinical guidelines.

In our study, we observed that there was no uniform recommendation for the option of conservative management, which corroborates with the Spine Patient Outcomes Research Trial. ${ }^{9}$

According to the NASS clinical guidelines, surgical decompression with fusion is the option indicated for patients with symptomatic spinal stenosis and degenerative lumbar spondylolisthesis, ${ }^{10}$ as we observed in our study.

The NASS suggests the addition of instrumentation in patients with symptomatic degenerative lumbar spondylolisthesis to improve fusion rates, improve clinical results, achieve better stability, and reduce the rate of future complications, ${ }^{11,12}$ which fully corroborates the recommendations of the doctors included in our study. 


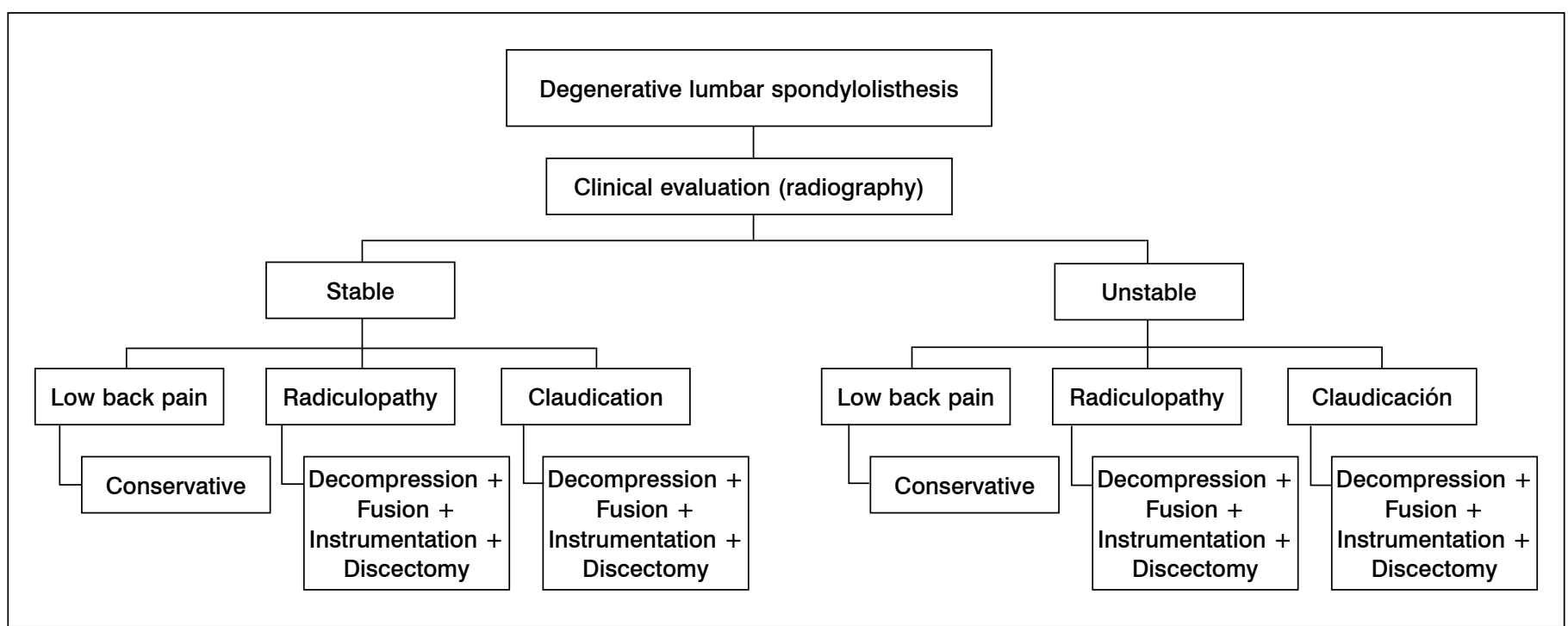

Figure 1. Flowchart of the guide for treatment of degenerative lumbar spondylolisthesis.

\section{CONCLUSION}

This study provides useful information that can be used in the preparation of guidelines for the treatment of degenerative lumbar spondylolisthesis.

In addition to being based on the degree of displacement, the medical decision is based on clinical presentation and the stability of the lumbar spine. The treatment of choice for degenerative lumbar spondylolisthesis with axial symptoms is conservative. The surgical treatment of choice for symptomatic spondylolisthesis with radiculopathy and/or claudication is decompression + posterolateral graft + transpedicular instrumentation + discectomy (graft).

Each patient should be holistically evaluated, in order to define the best treatment and thus achieve a satisfactory outcome.

All the authors declare that there are no potential conflicts of interest regarding this article.

CONTRIBUTION OF THE AUTHORS: Each author made significant individual contributions to the development of the manuscript. BG and GS were the major contributors to the concept, the design of the research protocol, and the writing of the manuscript. EM and PA contributed to the writing of the article and the critical revision of the manuscript content. BG and DP contributed to the collection and statistical analysis of the data. TG and PA contributed to the review and the final approval of the published version. All the authors contributed to the intellectual concept of the study.

\section{REFERENCES}

1. North American Spine Society. Evidence-based clinical guidelines for multidisciplinary spine care: diagnosis and treatment of degenerative lumbar spondylolisthesis. 2nd. ed. Burr Ridge, IL: NASS; 2008. Disponível em: https://www. spine.org/Documents/ResearchClinicalCare/Guidelines/Spondylolisthesis.pdf

2. Raymond J. Gardocki Francis X. Camillo. Degenerative spondylolisthesis. Other disorders of the spine. Campbell's Operative Orthopaedics, Chapter 44 1993-2050.e18.

3. O'Sullivan PB, Phyty GD, Twomey LT, Allison GT. Evaluation of specific stabilizing exercise in the treatment of chronic low back pain with radiologic diagnosis of spondylolysis or spondylolisthesis. Spine (Phila Pa 1976). 1997:22(24):2959-67.

4. Watters WC 3rd, Bono CM, Gilbert TJ, Kreiner DS, Mazanec DJ, Shaffer WO, et al. An evidence-based clinical guideline for the diagnosis and treatment of degenerative lumbar spondylolisthesis. Spine J. 2009:9(7):609-14.

5. Deyo RA, Mirza SK, Martin BI, KreuterW, Goodman DC, Jarvik JG. Trends, major medical complications, and charges associated with surgery for lumbar spinal stenosis in older adults. JAMA. 2010;303(13):1259-65.

6. Herkowitz HN, Kurz LT. Degenerative lumbar spondylolisthesis with spinal stenosis. A prospective study comparing decompression with decompression and intertransverse process arthrodesis. J Bone Joint Surg Am. 1991;73(6):802-8.
7. Schaeren S, Broger I, Jeanneret B. Minimum four-year follow-up of spinal stenosis with degenerative spondylolisthesis treated with decompression and, dynamic stabilization. Spine (Phila Pa 1976). 2008;33(18):E636-42.

8. Sthephen BH, Steven RC, Warren SB, Grady DMD, Norman H, Thomas BN. Designing clinical research and epidemiologic approach. 2nd. ed. Philadelphia: Lippincott; 2001.

9. Weinstein JN, Lurie JD, Tosteson TD, Hanscom B, Tosteson AN, Blood EA et al. Surgical versus nonsurgical treatment for lumbar degenerative spondylolisthesis. N Engl J Med. 2007;356(22):2257-70.

10. Park JH, Hyun SJ, Roh SW, Rhim SC. A comparison of unilaterallaminectomy with bilateral decompression and fusion surgery in the treatment of grade I lumbar degenerative spondylolisthesis. Acta Neurochir. 2012;154(7):1205-12.

11. Bridwell KH, Sedgewick TA, O'Brien MF, Lenke LG, Baldus C. The role of fusion and instrumentation in the treatment of degenerative spondylolisthesis with spinal stenosis. J Spinal Disord. 1993;6(6):461-72.

12. Rousseau MA, Lazennec JY, Bass EC, Saillant G. Predictors of outcomes after posterior decompression and fusion in degenerative spondylolisthesis. Eur Spine J. 2005;14(1):55-60. 